\title{
PEMBUATAN MEDIA INTERAKTIF BERBASIS POWER POINT UNTUK GURU SMA DALAM MENGHADAPI REVOLUSI INDUSTRI 4.0
}

\author{
Oleh: \\ I Nyoman Buda Hartawan ${ }^{1}$, Putu Praba Santika ${ }^{2}$, Ni Wayan Suardiati Putri ${ }^{3}$ I Ketut Setiawan ${ }^{4}$ \\ ${ }^{1234}$ STMIK STIKOM Indonesia \\ 1buda.hartawan@gmail.com
}

\begin{abstract}
Abstrak
Tingkat pendidikan masyarakat di suatu Negara menentukan perkembangan dari Negara tersebut. Peserta didik saat ini merupakan generasi yang secara karakter memiliki perbedaan dengan generasi sebelumnya, sehingga memerlukan metode pembelajaran yang juga berbeda. Penyajian materi secara menarik dan interaktif menjadi salah satu cara untuk mampu menarik perhatian peserta didik selama kegiatan belajar mengajar. Pada kegiatan tersebut terjadi proses transformasi pengetahuan dari guru kepada peserta didiknya. Hal ini menyebabkan perlu adanya media pembelajaran yang tepat agar proses transformasi pengetahuan dapat berjalan dengan lancar. Kegiatan pelatihan yang dilakukan adalah pembuatan media interaktif berbasis power point untuk guru SMA. Pelatihan ini menjadi solusi praktis yang mampu membantu guru dalam menyajikan materi pembelajaran yang menarik, interaktif, dan berbasis teknologi. Untuk mengukur tingkat keberhasilan kegiatan ini, peserta pelatihan diberikan tugas untuk menyelesaikan sebuah proyek membuat media interaktif. Dari hasil penilaian yang dilakukan terdapat $78 \%$ peserta selesai mengerjakan proyek sesuai dengan waktu yang ditentukan, sedangkan $22 \%$ belum selesai mengerjakan proyek. Meskipun demikian, kegiatan ini dinilai bermanfaat dan berhasil membantu guru dalam membuat media interaktif dengan memanfaatkan teknologi sesuai dengan bidang ilmunya masing-masing.
\end{abstract}

Kata Kunci: media pembelajaran, media interaktif, power point, revolusi industri 4.0, pendidikan 4.0

\begin{abstract}
The level of public education in a country determines the development of that country. Today's students are generations who characteristically have differences from previous generations so that they require different learning methods. The presentation of material interestingly and interactively is one way to be able to attract the attention of students during teaching and learning activities. In these activities the process of transforming knowledge from the teacher to the students takes place. This causes the need for appropriate learning media so that the process of transformation of knowledge can run smoothly. The training activities carried out were the creation of interactive power-based media for high school teachers. This training is a practical solution that can assist teachers in presenting interesting, interactive, and technologybased learning materials. To measure the success of this activity, trainees are given the task of completing a project to make interactive media. From the results of the assessment conducted, $78 \%$ of participants completed the project following the specified time, while $22 \%$ had not finished working on the project. Nevertheless, this activity is considered useful and successful in helping teachers create interactive media by utilizing technology following their respective fields of science.
\end{abstract}

Keywords: learning media, interactive media, power point, industrial revolution 4.0, education 4.0

\section{PENDAHULUAN PENDAHULUAN}

Era Revolusi Industri 4.0 saat ini memberikan dampak yang sangat besar terhadap dunia bisnis maupun perilaku dan aktivitas manusia. Perkembangan teknologi saat ini memungkinkan segala sesuatunya di kendalikan melalui smartphone, yang lebih dikenal dengan Internet of Things (loT) (Hartawan \& Sudiarsa, 2019). Akses internet 
yang sebelumnya hanya dapat diperoleh melalui warung internet (warnet), saat ini sudah banyak disediakan baik oleh pemerintah, sekolah, maupun pemilik usaha seperti warung, tempat makan, tempat kursus, toko, dan lain sebagainya. Penetrasi internet di Indonesia mencapai $64,8 \%$ dari total jumlah penduduk, dimana di perkotaan mencapai $74,1 \%$ dan pedesaan mencapai 61,6\% (APJII, 2019). Hal ini menunjukkan bahwa masyarakat perkotaan maupun pedesaan sudah mampu melakukan akses internet. Revolusi Industri 4.0 menyebabkan pemanfaatan teknologi digital di berbagai bidang semakin meningkat. Hal ini juga mendorong dunia pendidikan untuk beradaptasi menuju Pendidikan 4.0.

Pendidikan nasional adalah pendidikan yang berdasarkan Pancasila dan UndangUndang Dasar Negara Republik Indonesia Tahun 1945 yang berakar pada nilai-nilai agama, kebudayaan nasional Indonesia, dan tanggap terhadap tuntutan perubahan zaman (Kemdikbud, 2003). Ini menunjukkan bahwa pendidikan harus mampu beradaptasi dengan kondisi zaman saat ini, yaitu era revolusi industri 4.0. Hal ini menuntut dunia pendidikan harus berevolusi menuju Pendidikan 4.0. Guru perlu memiliki kompetensi di bidang teknologi untuk mampu menghadapi tantangan revolusi industri 4.0 (Fitriyah, 2019). Sekolah harus mampu memanfaatkan teknologi dalam mendukung proses pendidikan baik dalam kegiatan belajar mengajar maupun kegiatan manajemen dan operasional sekolah. Disamping itu, tantangan lain yang dihadapi oleh sekolah adalah peserta didik yang saat ini tergolong ke dalam generasi Z. Generasi Z lahir pada rentang tahun 2001 sampai dengan 2010. Generasi Z merupakan peralihan dari Generasi Milenial (Generasi Y) yang sedang menghadapi perkembangan teknologi. Selain itu, Generasi Z ini juga cenderung serba instan (Budiati et al., 2018). Peserta didik SMA saat ini berumur sekitar 15-18 tahun yang merupakan anak kelahiran tahun 2001-2004, yang tergolong generasi Z. Ini berarti bahwa teknik dan media pembelajaran yang digunakan oleh guru dalam mendidik peserta didik generasi $Z$ perlu disesuaikan.

Dunia pendidikan, kegiatan belajar mengajar adalah hal yang sangat penting untuk dilaksanakan di sekolah. Guru harus mampu menarik perhatian peserta didik untuk mendengarkan ketika sedang menjelaskan materi. Pemanfaatan media pembelajaran berbasis teknologi merupakan salah satu cara untuk dapat menarik perhatian peserta didik (Putri \& Suryati, 2019). Media pembelajaran yang menarik sangat penting dalam meningkatkan minat belajar siswa, sehingga siswa mampu memahami materi pelajaran menjadi lebih baik(Susanah, Fardah, \& Palupi, 2020)(Palupi, Khabibah, Lukito, \& Amin, 2020).

Kegiatan Pengabdian Masyarakat dilaksanakan di SMA Negeri 1 Blahbatuh, yang merupakan sebuah sekolah yang berlokasi di Kabupaten Gianyar, Provinsi Bali. Berdasarkan hasil wawancara dengan bagian kurikulum, menunjukkan bahwa sekolah sudah memiliki laboratorium komputer dan infrastruktur jaringan komputer. Disamping itu, sekolah sudah memiliki akses internet melalui jaringan wi-fi yang juga dapat digunakan oleh siswa. Guru-guru sudah terbiasa dalam penggunaan komputer dan membuat slide presentasi menggunakan power point. Sekolah juga sudah memiliki sistem e-learning, sehinga nantinya diharapkan materi yang dibuat dalam bentuk slide presentasi juga sekaligus menjadi konten pada sistem e-learning yang dimiliki. Secara pemanfaatan teknologi, SMA Negeri 1 Blahbatuh sudah memenuhi aspek kesiapan, sehingga perlu dilakukan peningkatan kemampuan guru dalam pemanfaatan teknologi tersebut untuk menuju pendidikan 4.0. Selama ini guru menggunakan power point dengan penyajian dalam bentuk teks dan animasi teks yang sederhana. Hal ini kurang menarik bagi siswa terutama ketika siswa ingin mempelajari kembali materi tersebut secara mandiri diluar kelas tanpa pengawasan guru. Sistem elearning yang dimiliki saat ini juga belum memuat konten materi secara lengkap, karena tidak semua guru mampu membuat materi dalam bentuk digital.

Kurikulum 2013 dikembangkan dengan penyempurnaan penguatan pola pembelajaran yang berpusat pada peserta didik, pembelajaran interaktif, pembelajaran secara jejaring, pembelajaran aktif-mencari, kemampuan belajar sendiri dan kelompok, serta pembelajaran berbasis multimedia (Kemendikbud, 2018). Hal ini menunjukkan bahwa perlunya materi pembelajaran disajikan secara menarik dan dapat dipelajari oleh siswa secara mandiri. Disamping itu juga, materi yang disajikan tersebut dapat diakses melalui media jejaring.

Berdasarkan permasalahan di atas, maka dilakukan kegiatan pengabdian kepada 
masyarakat di SMA Negeri 1 Blahbatuh, dengan judul Pelatihan Pembuatan Media Interaktif Berbasis Power Point untuk Guru SMA dalam Menghadapi Revolusi Industri 4.0. Target yang ingin dicapai dalam kegiatan ini adalah 1) Mengetahui tingkat keberhasilan peserta dalam menyelesaikan proyek media interaktif yang diberikan menggunakan power point 2) Mengukur tingkat kemandirian peserta dalam membuat proyek media interaktif menggunakan power point. Selain digunakan untuk membuat slide presentasi, power point juga dapat digunakan untuk membuat media interaktif (Monemi, Lufri, \& Leilani, 2017). Media interaktif dapat membantu siswa dalam memahami materi pelajaran dibandingkan dengan buku teks/ebook yang monoton (Armansyah, Sulton, \& Sulthoni, 2019). Kegiatan ini memperoleh dukungan yang sangat baik dari Kepala Sekolah maupun guru-guru di SMA Negeri 1 Blahbatuh. Hal ini ditunjukkan dengan kehadiran guru-guru selaku peserta pelatihan pada saat kegiatan pelatihan berlangsung dan mengikuti kegiatan sampai selesai.

\section{METODE}

Kegiatan Pengabdian Masyarakat ini dilakukan dengan melaksanakan pelatihan kepada guru-guru di SMA Negeri 1 Blahbatuh Gianyar. Jumlah guru yang mengikuti kegiatan pelatihan adalah 60 orang, yang terdiri dari berbagai macam bidang ilmu. Kegiatan Pengabdian Masyarakat dilaksanakan dalam 3 (tiga) tahap, yaitu: 1) Tahap Persiapan, 2) Tahap Pelaksanaan, 3) Tahap Evaluasi.

\section{1) Tahap Persiapan}

Pada tahap persiapan dilakukan diskusi, wawancara, dan observasi ke SMA Negeri 1 Blahbatuh untuk mengetahui kondisi dan sarana yang dimiliki. Disamping itu, juga dilakukan pengumpulan data terkait dengan jenis pelatihan yang dibutuhkan, materi yang perlu disampaikan, dan jumlah peserta yang akan diikutsertakan. Hal ini perlu dilakukan agar materi yang disampaikan mampu mengatasi permasalahan yang dihadapi. Selain itu, dengan mengetahui jumlah peserta yang akan diikutsertakan bertujuan untuk menentukan jumlah mentor dan fasilitator yang akan dilibatkan dalam kegiatan. Hal ini mengingat model kegiatan pelatihan dengan mengajak peserta mengikuti instruksi dari mentor, tidak dapat dilakukan dengan kecepatan yang seragam. Selalu saja ada peserta yang ketinggalan penjelasan dari mentor. Untuk itu, pada tahap persiapan ini dikumpulkan informasi untuk menentukan jumlah fasilitator yang akan dilibatkan untuk mendampingi peserta pelatihan, sehingga pelatihan dapat berjalan dengan lancar.

\section{2) Tahap Pelaksanaan}

Kegiatan Pengabdian Masyarakat ini dilaksanakan selama 2 hari yang meliputi pelatihan dasar power point, serta pembuatan media interaktif dan kuis dengan menggunakan power point. Kegiatan pelatihan diikuti oleh 60 peserta. Jumlah peserta yang mencapai 60 orang melibatkan 1 mentor dengan 10 fasilitator, dimana 1 fasilitator mendampingi 6 peserta. Sehingga peserta dapat dibantu mengikuti pelatihan selama kegiatan. Setiap peserta menggunakan 1 laptop selama kegiatan berlangsung. Jika ada pertanyaan peserta dapat langsung menyampaikannya kepada mentor atau jika ada peserta yang ketinggalan dalam penjelasan dapat langsung meminta bantuan kepada fasilitator. Peserta dapat dilayani dengan cepat karena 1 fasilitator mendampingi 6 peserta. Selain itu, peserta juga sudah terbiasa menggunakan komputer sehingga pelatihan dapat dilakukan secara lebih detail (advanced).

\section{3) Tahap Evaluasi}

Setelah kegiatan selesai dilaksanakan, selanjutnya dilakukan evaluasi untuk mengetahui keberhasilan dari kegiatan yang sudah dilaksanakan. Evaluasi dilakukan dengan memberikan proyek kepada peserta di sesi terakhir pelatihan dan melakukan penilaian selama peserta mengerjakan proyek tersebut. Disamping itu juga tujuan dari pemberian proyek ini adalah untuk mengetahui tingkat pemahaman peserta terhadap materi pelatihan yang sudah disampaikan.

\section{HASIL DAN PEMBAHASAN}

\section{1) Studi Lapangan}

Sebelum pelaksanaan kegiatan pengabdian masyarakat, terlebih dahulu dilakukan studi lapangan. Tujuan dari studi lapangan adalah untuk mengetahui informasi tentang kebutuhan jenis pengabdian masyarakat, materi dan teknologi yang digunakan. Hasil studi lapangan menunjukkan bahwa SMA Negeri 1 Blahbatuh sudah memiliki 
laboratorium komputer, jaringan komputer, e-learning, dan LCD projector di ruangan kelas. Hasil wawancara dengan bagian kurikulum menunjukkan bahwa penggunaan power point dalam membuat slide presentasi sudah dilakukan, namun masih belum maksimal dalam pemanfaatan fitur-fiturnya, seperti: pembuatan animasi, media interaktif, dan kuis. Beliau menyadari bahwa dengan adanya animasi dan media interaktif pada slide presentasi akan mampu menarik perhatian peserta didik dalam kegiatan belajar mengajar.

Disamping memperoleh informasi tentang sarana yang dimiliki, materi dan kondisi SDM, juga dilakukan penyesuaian jadwal pelatihan. Hal ini dilakukan mengingat guru yang akan dilibatkan mencapai 60 orang sehingga diperlukan penyesuaian waktu untuk pelaksanaan pelatihan.

\section{2) Pelaksanaan Kegiatan Pengabdian} Masyarakat

Setelah melakukan studi lapangan, selanjutnya dilaksanakan kegiatan pengabdian masyarakat dalam bentuk pelatihan pembuatan media interaktif menggunakan power point kepada guru sesuai dengan jadwal yang telah disepakati.

Pelatihan dilaksanakan di laboratorium komputer, mengingat kapasitas ruangan ini cukup besar dan mampu menampung seluruh jumlah peserta. Disamping itu, kemudahan akses internet membantu peserta dalam mencari bahan-bahan untuk kebutuhan pembuatan media interaktif dengan power point, seperti gambar, video, audio, dan materi.

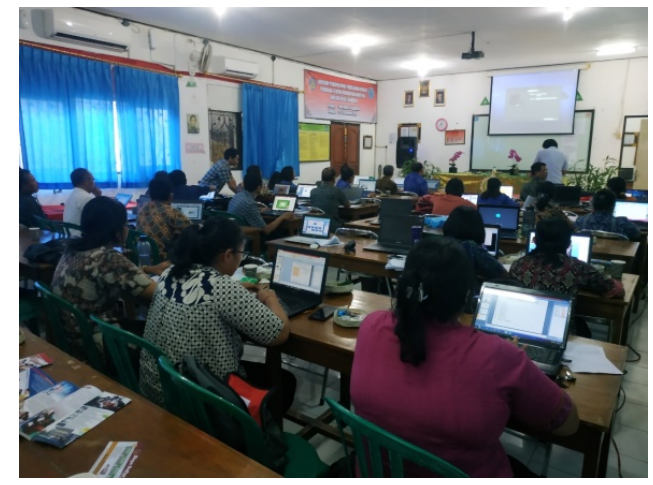

Gambar 1 Peserta Pelatihan

Pada hari pertama dilakukan pengenalan dasar power point dalam pembuatan slide presentasi. Hal ini dilakukan untuk mengetahui kemampuan peserta dalam menguasai power point, mengingat jumlah peserta yang mencapai 60 orang. Ini nantinya akan mempengaruhi metode yang digunakan oleh mentor dalam penyampaian materi. Selanjutnya mentor mulai menyampaikan materi dengan mengacu pada modul yang telah dibuat dan dibagikan sebelumnya. Setiap 6 peserta didampingi oleh 1 orang fasilitator, sehingga ketika ketinggalan materi, peserta tetap mampu mengikuti dengan pendampingan dari fasilitator. Pada kegiatan ini dilibatkan 10 orang fasilitator.

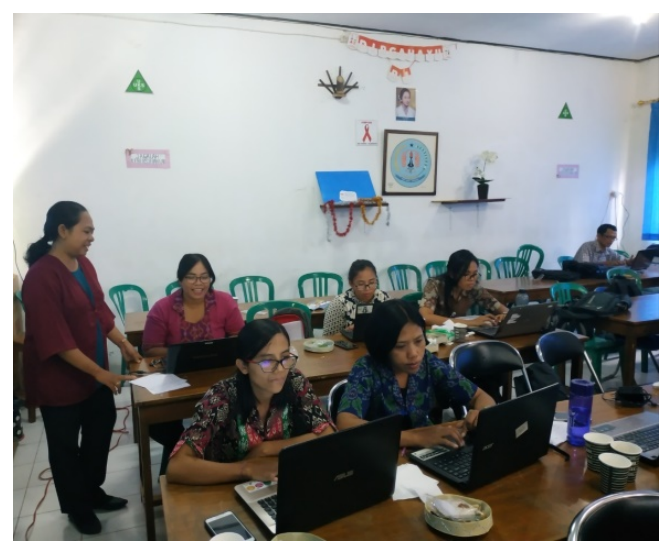

Gambar 2 Pendampingan oleh fasilitator

Pada hari kedua dilanjutkan dengan pelatihan pembuatan media interaktif dan kuis menggunakan Power Point. Antusiasme peserta juga masih tinggi pada hari kedua. Hal ini dibuktikan dari kehadiran peserta. Power point merupakan aplikasi yang sudah biasa digunakan oleh guru dalam membuat materi pelajaran.

Pelatihan pertama yang telah dilaksanakan menunjukkan bahwa pengetahuan dan keterampilan dari peserta tidak merata, namun semangat belajar yang ditunjukkan sangat tinggi. Peserta sudah melengkapi diri dengan laptop dan aplikasi yang siap digunakan. Bahkan ada yang sudah membawa mouse sendiri karena dalam pembuatan media interaktif disarankan untuk menggunakan mouse agar lebih memudahkan dalam navigasi.

Dalam mendidik Generasi $Z$ yang sudah terbiasa dalam lingkungan teknologi, maka guru sebagai pendidik juga harus dilengkapi dengan kemampuan teknologi yang baik. Hal ini sejalan dengan kebutuhan untuk dapat bersaing di era revolusi industri 4.0 yang salah satunya adalah memiliki kemampuan literasi 
teknologi. Dengan menggunakan media interaktif guru-guru menyadari akan mampu menarik perhatian peserta didik untuk lebih menyukai materi pembelajaran, terutama terkait dengan matematika. Peserta juga menyiapkan catatan selama pelatihan agar setelah pelatihan dapat dipelajari kembali. Semangat belajar guruguru yang tinggi juga memicu mentor dan fasilitator menjadi lebih semangat dalam memberikan pelatihan.

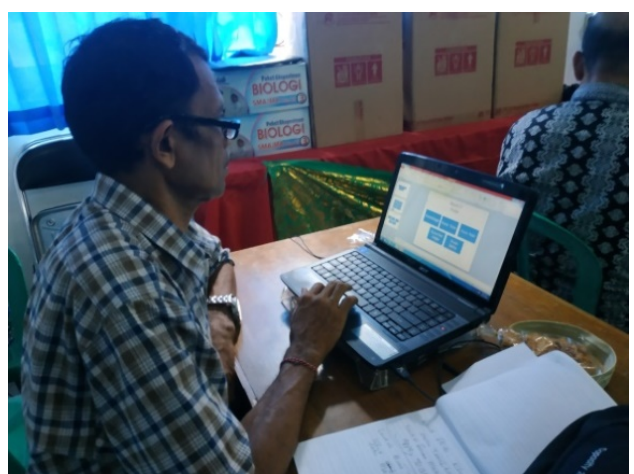

Gambar 3 Peserta menyiapkan catatan

Agar pelatihan dapat dilaksanakan sesuai dengan waktu yang telah ditetapkan, sebelum pelatihan peserta sudah diminta untuk menyiapkan rancangan materi yang akan dibuatkan media interaktifnya, sehingga pada saat pelatihan peserta dapat langsung mengkonversi materi yang telah dibuat ke dalam bentuk media interaktif menggunakan Power Point.

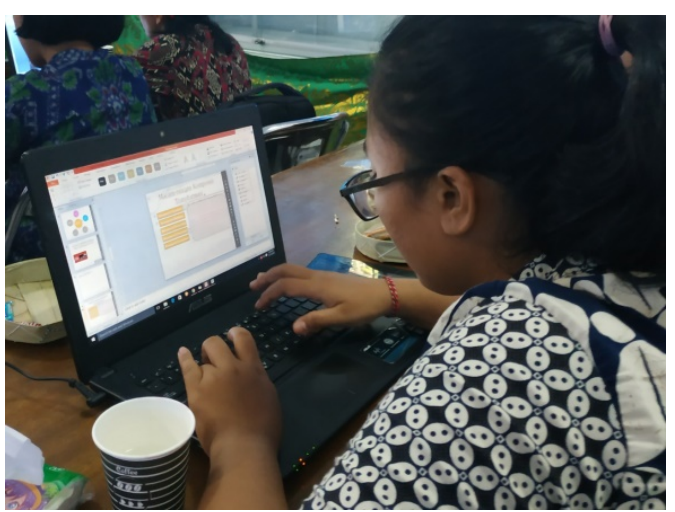

Gambar 4 Peserta mengikuti intruksi mentor

Disamping itu, peserta sudah terbiasa menggunakan laptop sehingga dapat mengikuti pelatihan pembuatan media interaktif dengan lancar. Pelatihan juga dilengkapi dengan modul yang dapat dijadikan sebagai panduan oleh peserta dalam mengikuti pelatihan atau dapat digunakan sebagai panduan dalam pembuatan media interaktif setelah pelatihan selesai.

Pelaksanaan pelatihan berlangsung selama 6 jam setiap harinya dan diikuti secara penuh oleh peserta pelatihan. Walaupun kegiatan pengabdian masyarakat sudah selesai dilaksanakan, namun konsultasi tentang kendala yang dihadapi dalam pembuatan media interaktif masih dapat dilakukan secara online. Hal ini adalah bentuk layanan yang diberikan kepada masyarakat dalam hal ini adalah guru-guru untuk mengatasi kendala yang dihadapi dalam pembuatan media interaktif menggunakan power point.

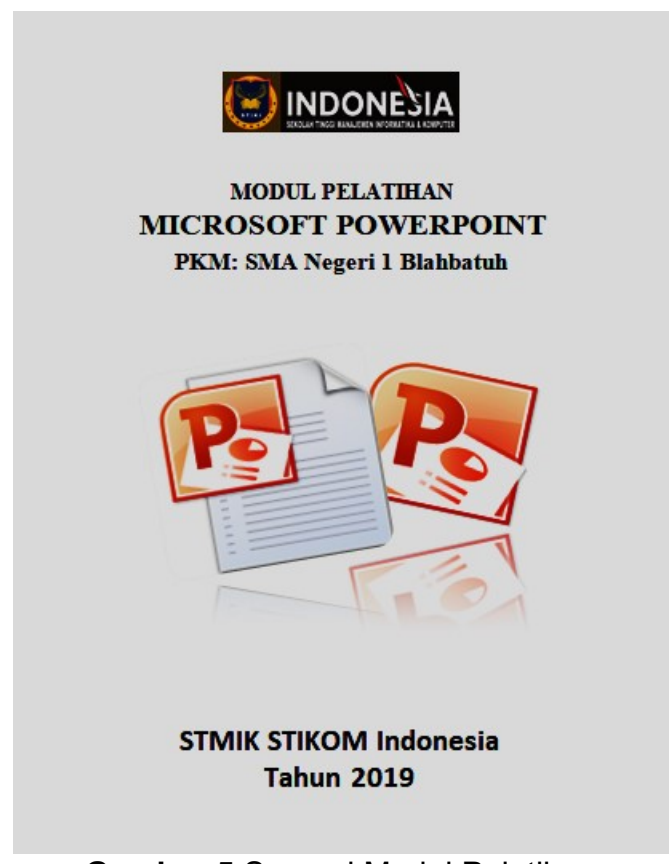

Gambar 5 Sampul Modul Pelatihan

3) Evaluasi Hasil

Evaluasi adalah kegiatan yang harus dilakukan untuk mengukur tingkat keberhasilan sebuah kegiatan, dan dijadikan sebagai pertimbangan dalam melaksanakan kegiatan berikutnya. Selama kegiatan berlangsung, peserta diminta untuk membuat media interaktif sesuai dengan arahan dari mentor. Sedangkan pada akhir sesi pelatihan, peserta diminta untuk membuat sebuah media interaktif secara mandiri tanpa arahan dari mentor. Aktivitas yang dilakukan oleh peserta pelatihan selama mengerjakan proyek yang diminta dicatat oleh fasilitator sebagai bentuk penilaian terhadap hasil kerja yang dilakukan oleh para peserta. Untuk memudahkan 
pembacaan, maka hasil evaluasi disajikan dalam bentuk grafik.

Pada Gambar 6 dapat dilihat hasil penilaian yang dilakukan oleh fasilitator. Terdapat $78 \%$ peserta yang mengerjakan proyek sampai dapat berfungsi, walaupun masih perlu dirapikan lagi, sedangkan $22 \%$ peserta belum selesai mengerjakan proyek. Meskipun demikian, secara keseluruhan, peserta sudah dianggap mampu memahami fungsi dan tata letak menu yang digunakan dalam membuat media interaktif menggunakan power point. Kegiatan pengabdian masyarakat yang dilakukan memberikan manfaat secara langsung kepada 60 orang guru dalam membuat media interaktif berbasis power point.

\section{Hasil Pengerjaan Project}

- Project selesai $\quad$ Project belum selesai

\section{$22 \%$}

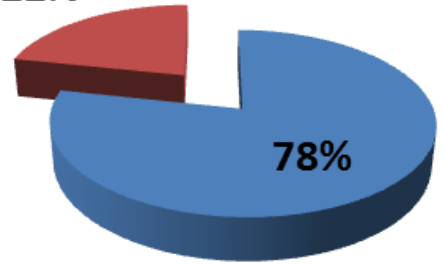

Gambar 6 Hasil Pengerjaan Project

\section{Aktivitas Peserta Pelatihan}

- Bekerja secara mandiri

- Bekerja masih melihat modul

- Bekerja dengan bantuan peserta lain

- Bekerja dengan bantuan fasilitator

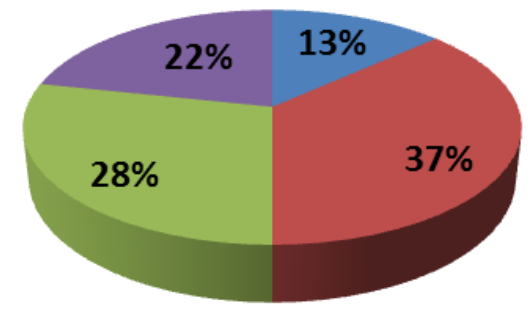

\section{Gambar 7 Aktifitas Peserta Pelatihan}

Pada Gambar 7 dapat dilihat aktivitas dari peserta selama mengerjakan proyek yang diminta. Fasilitator mengamati setiap peserta dalam mengerjakan proyek yang diminta. Dari hasil pengamatan yang dilakukan diperoleh bahwa terdapat $13 \%$ peserta yang mampu bekerja secara mandiri, $37 \%$ peserta bekerja dengan melihat modul, $28 \%$ peserta bekerja dengan bantuan peserta yang lain, dan $22 \%$ bekerja dengan bantuan fasilitator. Walaupun jumlah peserta yang mampu mengerjakan proyek secara mandiri tidak mencapai $75 \%$, namun hasil ini masih dimaklumi mengingat kompleksitas menu pada pembuatan media interaktif cukup tinggi, sehingga kedepannya perlu adanya kegiatan pelatihan secara berkelanjutan.

\section{SIMPULAN DAN SARAN}

Setelah kegiatan pelatihan pembuatan media interaktif berbasis Power Point ini dilaksanakan, terdapat simpulan yang perlu disampaikan, yaitu dari penilaian yang dilakukan, sebanyak $78 \%$ peserta mampu menyelesaikan proyek pembuatan media interaktif yang diberikan menggunakan power point. Peserta mampu membuat media interaktif berbasis power point baik secara mandiri sebesar $13 \%$, bantuan modul pelatihan sebesar $37 \%$, bantuan peserta lain sebesar $28 \%$, maupun bantuan dari fasilitator sebesar $22 \%$. Pihak sekolah sangat antusias dalam meningkatkan kompetensi guru dalam memenuhi tuntutan pendidikan di era revolusi industri 4.0, hal ini dapat dilihat dari dukungan Kepala Sekolah dalam memfasilitasi dan memberikan izin kepada 60 guru untuk ikut serta dalam pelatihan mulai dari awal sampai selesai.

Saran yang perlu disampaikan sebagai bentuk rekomendasi kegiatan PKM selanjutnya adalah perlu adanya kolaborasi antara guru yang mampu menggunakan teknologi dan yang kurang dalam penggunaan teknologi dalam menghasilkan media pembelajaran interaktif. Keterbatasan jumlah staff IT di sekolah, menyebabkan sekolah perlu membentuk Ekstra/Club Komputer/IT di kalangan siswa. Harapannya selain melatih siswa dalam mengembangkan minat dan bakatnya, juga dapat membantu guru yang menemukan kendala dalam pemanfaatan IT untuk kegiatan belajar mengajar. Hal ini mengingat guru memiliki bidang ilmu yang beraneka ragam, sedangkan siswa yang 
notabene merupakan Generasi Z-Y mampu belajar teknologi lebih cepat.

\section{DAFTAR PUSTAKA}

APJII. (2019). Penetrasi \& Profil Perilaku Pengguna Internet Indonesia Tahun 2018. Apjii, 51. Retrieved from www.apjii.or.id

Armansyah, F., Sulton, \& Sulthoni. (2019). Multimedia Interaktif Sebagai Media Visualisasi Dasar-Dasar Animasi. Jurnal Kajian Teknologi Pendidikan, 2(3), 224229.

https://doi.org/10.17977/um038v2i32019 p224

Budiati, I., Susianto, Y., Adi, W. P., Ayuni, S., Reagan, H. A., Larasaty, P., ... Saputri, V. G. (2018). Statistik Gender Tematik: Profil Generasi Milenial Indonesia.

Fitriyah, R. N. (2019). Pengembangan Kompetensi Guru di Era Revolusi Industri 4.0 melalui Pendidikan dan Pelatihan. 2019: Seminar Nasional Multi Disiplin IImu Dan Call for Papers, (1), 359-364. Retrieved from https://www.unisbank.ac.id/ojs/index.ph p/sendi_u/article/view/7302

Hartawan, I. N. B., \& Sudiarsa, I. W. (2019). Analisis Kinerja Internet of Things Berbasis Firebase Real-Time Database. Jurnal RESISTOR (Rekayasa Sistem Komputer), 2(1), 6-17. https://doi.org/10.31598/jurnalresistor.v2 i1.371

Kemdikbud. Undang-Undang Republik Indonesia Nomor 20 Tahun 2003 Tentang Sistem Pendidikan Nasional Dengan Rahmat Tuhan Yang Maha Esa
Presiden Republik Indonesia. , (2003).

Kemendikbud. (2018). Peraturan Menteri Pendidikan dan Kebudayaan Nomor 36 Tahun 2018 tentang Perubahan atas Peraturan Menteri Pendidikan dan Kebudayaan Nomor 59 Tahun 2014 tentang Kurikulum 2013 Sekolah Menengah Atas/Madrasah Aliyah. Permendikbud, 1-12.

Monemi, R., Lufri, \& Leilani, I. (2017). Pengembangan Multimedia Interaktif Berbasis Power Point Disertai Games Kuis Course Maze Pada Materi Sistem Ekskresi Untuk Peserta Didik Kelas Viii Smp Developing Interactive Multimedia Based on Power Point With Course Maze Games Kuis About Excretion Syste. Journal Biosains, 1(2), 252-260. Retrieved from http://ejournal.unp.ac.id/students/index.p $\mathrm{hp} / \mathrm{bio} /$ issue/download/355/56

Palupi, E. L. W., Khabibah, S., Lukito, A., \& Amin, S. M. (2020). Pelatihan Pembelajaran Matematika Realistik (Pmr) Dengan Media Berbahan Bekas Di Sekolah Dasar. ABDI, 5(2), 97-105.

Putri, N. W. S., \& Suryati, K. (2019). Pengembangan Media Pembelajaran Program Linier Berbasis Geogebra di STMIK STIKOM INDONESIA. Jurnal Matematika, $\quad 9(2), \quad 111$. https://doi.org/10.24843/jmat.2019.v09.i 02.p117

Susanah, Fardah, D. K., \& Palupi, E. L. W. (2020). Pelatihan Pembuatan Media Pembelajaran Matematika Di Sd Karah I Surabaya. ABDI, 2(2), 83-88. 